\title{
Morphological and Morphometric Analysis of Mental Foramen in Dry, Human Mandibles of South India
}

\author{
Mangala $\mathbf{S}^{1}$, Shruthi B $\mathbf{N}^{2}$ \\ ${ }^{1}$ Associate Professor, ${ }^{2}$ Professor and Head, \\ Department of Anatomy, Raja Rajeswari Medical College and Hospital, Bangalore, Karnataka, India
}

Corresponding Author: Mangala. S

\begin{abstract}
Background: Mental foramen is a key factor in many of the surgical as well as clinical procedures in routine clinical practice.

The variations of mental foramen with respect to position, size and number does significantly alter the clinical implications of various intraoral treatments.

In this light, the present study on the position and morphological variants of mental foramen holds significance.
\end{abstract}

Aims and Objectives: To study morphological and morphometric analysis of mental foramen in dry human mandibles of South India

Materials and Methods: 50 dried adult Human mandibles of unknown sex with complete dentition and intact alveolar margin were studied

The morphometric analysis was done using vernier calipers

Results: In the present study, the most common position of mental foramen was of type 4 (in line with the $2^{\text {nd }}$ premolar) $62 \%$ cases on Right and $66 \%$ cases on Left side

The next common position was Type 3(Between the premolars) $24 \%$ cases on Right side and $18 \%$ cases on the left side

The mean distance between Symphysis menti and anterior margin of mental foramen was $23.4 \mathrm{~mm}$ and $23.2 \mathrm{~mm}$ on Right and left side respectively and the mean distance between posterior margin of mental foramen and posterior border of ramus was $62.2 \mathrm{~mm}$ and 61.5 $\mathrm{mm}$ on Right and left sides respectively

Conclusion: The present study has thrown light on the common position and morphometric variations of mental foramen in a given South Indian population.

This information will be valuable to the dental surgeons for localization of Neurovascular bundle emerging through mental foramen and for delivering local anesthesia effectively for placement of dentures/implants and other invasive procedures

Key Words: Mental foramen, Human mandible, Morphology, Morphometry

\section{INTRODUCTION}

The mental foramen is an oval/circular opening on the anterior surface of the mandible, located below or between the premolars, approximately midway between the alveolar crest and lower border of the mandible ${ }^{1}$

The mental foramen marks the termination of mandibular canal in the mandible, through which the inferior alveolar nerves and vessels pass

At this point, the mandibular canal bifurcates and forms the mental and incisive canals.

The mental bundle passes through the mental foramen and supplies sensory innervations and blood supply to the soft tissues of the chin, lower lip and gingiva on the ipsilateral side of the mandible ${ }^{2}$. Mental foramen is a strategically important anatomical landmark to facilitate surgical, local anesthetic and other invasive procedures for dental surgeons, performing periapical surgery in the mental region of 
the mandible. Its Anatomy is important for evaluating the morphometric symmetry of mental triangle, microscopic and macroscopic morphology, maturity of the Human mandible and is an excellent point to study bone remodelling ${ }^{1}$

Studying the position and morphological variation of the mental foramen is very important as it will be helpful to localize the important maxillofacial neurovascular bundle passing through mental foramen.

\section{Need for the study}

The position of mental foramen varies among racial groups and genders.

Despite the significance of mental foramen, little attention has been given to the study of morphology, most common location of foramen and associated anatomical characteristics in Mandibles of South India.

Hence, considering the importance of mental foramen, the present study shall be undertaken to investigate the morphology and variations in the position of mental foramen by the morphometric assessment with respect to the surgically encountered anatomical landmarks.

\section{Objectives of the study}

The aims of the present study are:

1) To determine the most common position of mental foramen in South Indian population in relation to the lower teeth and compare the results with those reported for other population

2) To determine the position of the mental foramen in relation to the mandibular symphysis, the posterior border of ramus of mandible, the lower border of the mandible and the alveolar crest on dry adult mandibles

\section{MATERIALS AND METHODS}

The present study was conducted in the Department of Anatomy, Rajarajeswari Medical College and Hospital, Bangalore.

Fifty dried adult human mandibles with complete dentition and intact alveolar margin of unknown sex were used for the study

The mandibles for the study was procured from the Department of Anatomy of the Institution as well as from the $1^{\text {st }}$ year medical students

The following parameters were observed in the mandibles during the study

1) shape and number of mental foramen

2) absence/presence of accessory mental foramen

3) The morphometric measurements were recorded using vernier calipers as follows:

a) The relation of mental foramen with lower teeth-The position of the mental foramen was recorded as lying in line with the long axis of a tooth/interdental space in one of the six relations:

Type 1-Anterior to $1^{\text {st }}$ premolar

Type 2-Below the $1^{\text {st }}$ premolar

Type 3-Between the premolars

Type 4-Below the $2^{\text {nd }}$ premolar

Type 5-Posterior to $2^{\text {nd }}$ premolar

Type 6-Below the $1^{\text {st }}$ molar

b) Location of mental foramen was identified by using following parameters:

1) Distance between anterior margin of mental foramen and symphysis menti

2) Distance between posterior margin of mental foramen and posterior border of ramus

3) Distance between superior margin of mental foramen and alveolar crest

4) Distance between inferior margin of mental foramen and lower border of body of mandible

For measuring the parameters, a standard horizontal plane as defined by Morrant was utilized which states that the mandible when placed on a horizontal surface, the lower border of the mandible comes into greatest contact when vertical pressure is applied to the $2^{\text {nd }}$ molar teeth

The measurements were recorded independently by 2 observers and the mean of the values recorded.

The findings were charted, analyzed and compared with findings of other 
Mangala S et.al. Morphological and morphometric analysis of mental foramen in dry, human mandibles of South India.

workers and studies on different

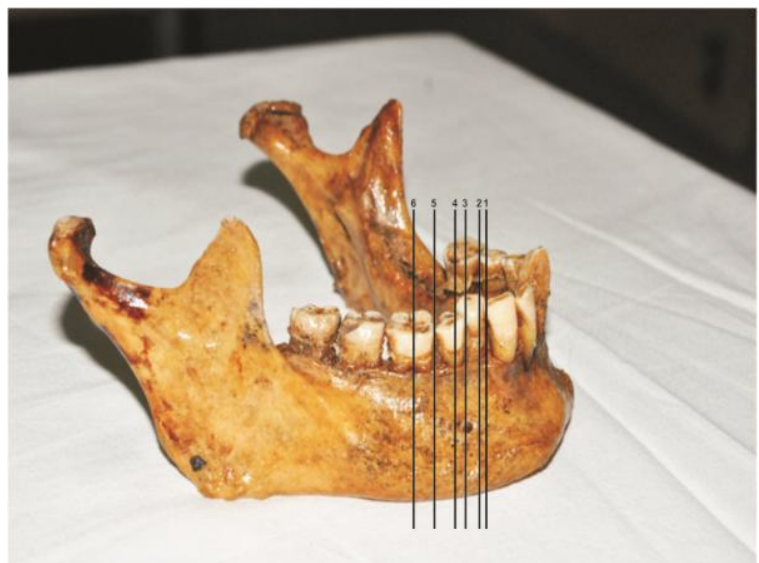

Figure 1: $1 / 2 / 3 / 4 / 5 / 6$ - the lines showing relation of mental foramen to the lower teeth / interdental space (Types 1 to 6 as mentioned earlier)

\section{RESULTS}

The mental foramen was present in all mandibles.

It was predominantly present as an oval opening in $62 \%$ of the cases

Rounded openings were observed in $38 \%$ of the cases

There was one mandible with accessory mental foramen on Right side (Figure 3) geographical locations and ethnic groups.

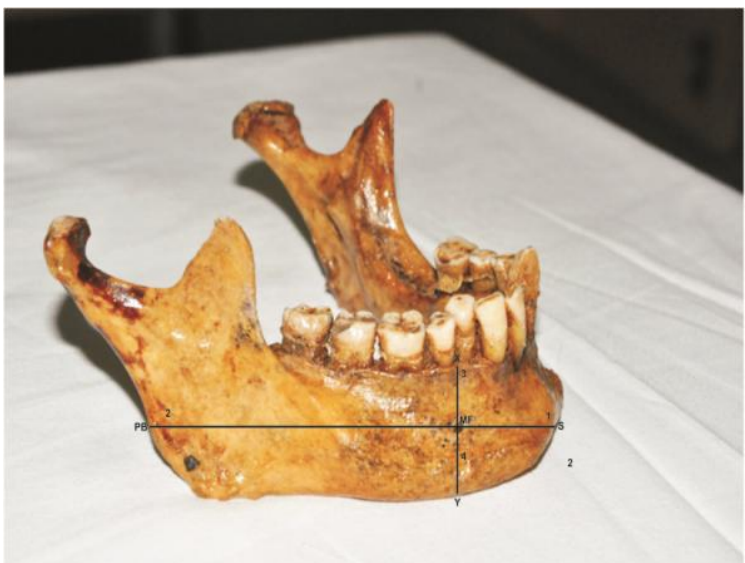

Figure 2: S- Symphysis manti, MF-mental foramen, PBposterior border of ramus of Mandible, $\mathrm{X}$-alveolar crest, $\mathrm{Y}$ lower border of body of Mandible,1- Distance between $S$ and MF, 2- Distance between MF and PB, 3- Distance between $X$ and MF and 4- Distance between MF and $Y$.

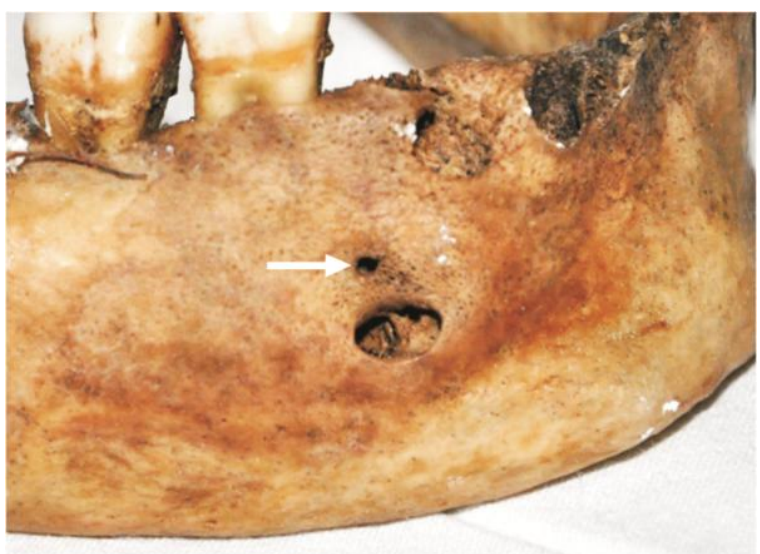

Figure -3 -Accessory Mental foramen

TABLE-1:Shape of the Mental Foramen(MF)-Comparison with other studies

\begin{tabular}{|c|c|c|c|c|c|c|}
\hline Shape & $\begin{array}{l}\text { Present study 2021, } \\
\text { South India } \\
(\mathrm{n}=50)\end{array}$ & $\begin{array}{l}\text { Ajay Parmar }{ }^{2} \\
\text { 2012,Eastern } \\
\text { India }(\mathbf{n}=50)\end{array}$ & $\begin{array}{l}\text { Siddiqui }^{8} \\
\text { 2010,Western } \\
\text { India(n=93) }\end{array}$ & $\begin{array}{l}\text { Ilayperuma9 } \\
\text { 2009,Srilanka } \\
(\mathbf{n}=51)\end{array}$ & $\begin{array}{l}\text { Fabian }^{10} \\
\text { 2007,Tanzania } \\
(\mathrm{n}=100)\end{array}$ & $\begin{array}{l}\text { Prabodha }^{11} \\
\text { 2006,Srilanka } \\
(\mathrm{n}=24)\end{array}$ \\
\hline oval & $62(62 \%)$ & $69(69 \%)$ & $65(70 \%)$ & $30(59 \%)$ & $54(54 \%)$ & $16(66.7 \%)$ \\
\hline Rounded & $38(38 \%)$ & $31(31 \%)$ & $28(30 \%)$ & $21(41 \%)$ & $46(46 \%)$ & $8(33.33 \%)$ \\
\hline
\end{tabular}

The most commonly present position of mandibular foramen in relation to the lower set of teeth was in line with the $2^{\text {nd }}$ premolar-Type 4

This position was present in $62 \%$ cases on the right side and $66 \%$ cases on the left side

TABLE-2:Position of the Mental foramen in relation to Lower teeth/Interdental space(comparison with other studies)

\begin{tabular}{|c|c|c|c|c|c|c|c|c|}
\hline study & location & year & Type 1 & Type 2 & Type 3 & Type 4 & Type 5 & Type 6 \\
\hline Present study $(\mathrm{n}=50)$ & Southern India & 2021 & - & - & $\begin{array}{l}\text { R12(24\%) } \\
\text { L10(20\%) }\end{array}$ & $\begin{array}{l}31(62 \%) \\
33(66 \%)\end{array}$ & $\begin{array}{l}5(10 \%) \\
4(8 \%)\end{array}$ & $\begin{array}{l}2(4 \%) \\
3(6 \%)\end{array}$ \\
\hline Ajay parmar ${ }^{2}$ et al $(\mathrm{n}=50)$ & Eastern India & 2012 & - & - & $\begin{array}{l}\text { R11(21.6\%) } \\
\text { L10 }(19.6 \%)\end{array}$ & $\begin{array}{l}33(64.7 \%) \\
34(66.7 \%) \\
\end{array}$ & $\begin{array}{l}4(7.8 \%) \\
5(9.8 \%) \\
\end{array}$ & $\begin{array}{l}2(3.9 \%) \\
1(2 \%) \\
\end{array}$ \\
\hline Siddiqui $^{8}(\mathrm{n}=93)$ & Western India & 2010 & $\begin{array}{l}\mathrm{R}(1.07 \%) \\
\mathrm{L}(1.07 \%)\end{array}$ & $\begin{array}{l}6(6.45 \%) \\
8(8.60 \%) \\
\end{array}$ & $\begin{array}{l}39(41.93 \%) \\
33(35.48 \%)\end{array}$ & $\begin{array}{l}41(44.08 \%) \\
43(46.23 \%)\end{array}$ & $\begin{array}{l}6(6.45 \%) \\
8(8.60 \%) \\
\end{array}$ & - \\
\hline Ilayperumal $^{9}(\mathrm{n}=51)$ & Srilanka & 2009 & - & - & $26.47 \%$ & $52.94 \%$ & - & - \\
\hline Yesilurt $^{5}(\mathrm{n}=70)$ & Turkey & 2008 & - & - & $\begin{array}{l}34.3 \% \\
25.7 \% \\
\end{array}$ & - & - & - \\
\hline Fabian ${ }^{10}(\mathrm{n}=100)$ & Tanzania & 2007 & - & - & - & $45 \%$ & $35 \%$ & - \\
\hline Kim et $\mathrm{al}^{12}(\mathrm{n}=72)$ & Korea & 2006 & - & - & $26.8 \%$ & $64.3 \%$ & - & - \\
\hline $\operatorname{Ngeow}^{13}(n=169)$ & Malaysia & 2003 & - & - & $19.6 \%$ & $69.2 \%$ & - & - \\
\hline Gingori $^{14}(n=361)$ & Turkey & 2006 & - & - & $71.5 \%$ & $22.4 \%$ & - & - \\
\hline
\end{tabular}


Mangala S et.al. Morphological and morphometric analysis of mental foramen in dry, human mandibles of South India.

The mean distance between anterior margin of mental foramen and symphysis menti was $23.4 \mathrm{~mm}$ and $23.2 \mathrm{~mm}$ on Right and Left sides respectively.

Mean distance between posterior margin of mental foramen and posterior border of ramus was $62.2 \mathrm{~mm}$ and $61.5 \mathrm{~mm}$ on Right and left sides respectively
Mean distance between superior margin of mental foramen and alveolar crest was $10.6 \mathrm{~mm}$ on right side and $10.3 \mathrm{~mm}$ on left side.

Mean distance between inferior margin of mental foramen and lower border of body of the mandible was $10.1 \mathrm{~mm}$ on right side and $9.9 \mathrm{~mm}$ on the left side

TABLE-3:Situation of Mental foramen with respect to Mandibular parameters(comparison with other studies)

\begin{tabular}{|c|c|c|c|c|c|c|c|c|}
\hline location & $\begin{array}{l}\text { Southern } \\
\text { India }\end{array}$ & $\begin{array}{l}\text { Eastern } \\
\text { India }\end{array}$ & $\begin{array}{l}\text { Western } \\
\text { India }\end{array}$ & Turkey & korea & Srilanka & Thailand & $\begin{array}{l}\text { North } \\
\text { India }\end{array}$ \\
\hline year & 2021 & 2012 & 2010 & 2008 & 2006 & 2006 & 2006 & 1992 \\
\hline Variable studied & Mean values & Mean values & Mean values & $\begin{array}{l}\text { Mean } \\
\text { values }\end{array}$ & & & & \\
\hline $\begin{array}{l}\text { Distance between MF } \\
\& S\end{array}$ & $\begin{array}{l}\mathrm{R}=23.4 \\
\mathrm{~L}=23.2\end{array}$ & $\begin{array}{l}\mathrm{R}=23.3 \\
\mathrm{~L}=22.5\end{array}$ & $\begin{array}{l}\mathrm{R}=18.8 \\
\mathrm{~L}=19.6\end{array}$ & $\begin{array}{l}R=19.18 \\
L=19.37\end{array}$ & & 26.52 & & 23.6 \\
\hline $\begin{array}{l}\text { Distance between } \\
\text { MF\&PB }\end{array}$ & $\begin{array}{l}\mathrm{R}=62.2 \\
\mathrm{~L}=61.5\end{array}$ & $\begin{array}{l}\mathrm{R}=61.3 \\
\mathrm{~L}=62.5\end{array}$ & $\begin{array}{l}\mathrm{R}=48.8 \\
\mathrm{~L}=47.9\end{array}$ & $\begin{array}{l}R=48.58 \\
L=19.37\end{array}$ & & 68.85 & & 76.2 \\
\hline $\begin{array}{l}\text { Distance between MF } \\
\& \mathrm{X}\end{array}$ & $\begin{array}{l}\mathrm{R}=10.6 \\
\mathrm{~L}=10.3\end{array}$ & $\begin{array}{l}\mathrm{R}=10.6 \\
\mathrm{~L}=10.3\end{array}$ & $\begin{array}{l}\mathrm{R}=10.2 \\
\mathrm{~L}=10\end{array}$ & $\begin{array}{l}\mathrm{R}=10.5 \\
\mathrm{~L}=10.64\end{array}$ & & & & 15.3 \\
\hline $\begin{array}{l}\text { Distance between MF } \\
\& Y\end{array}$ & $\begin{array}{l}\mathrm{R}=10.1 \\
\mathrm{~L}=9.9\end{array}$ & $\begin{array}{l}\mathrm{R}=10.7 \\
\mathrm{~L}=10.7\end{array}$ & $\begin{array}{l}\mathrm{R}=9.9 \\
\mathrm{~L}=10.1\end{array}$ & $\begin{array}{l}\mathrm{R}=9.44 \\
\mathrm{~L}=9.46\end{array}$ & 14.33 & 12.25 & 14.88 & 14.0 \\
\hline
\end{tabular}
of the mandible

\section{DISCUSSION}

Knowledge of location of foramen in maxillofacial region especially mental foramen is necessary especially in a clinical situation where regional nerve blocks are required for open as well as endoscopic surgical procedures in order to avoid injury to corresponding nerves.

In the present study, the most commonly encountered shape of the mental foramen was oval (62\%) followed by a round shape $(38 \%)$ as per Table-1

This predominance of the oval shape has also been reported by other workers, the value of which vary in different population

Ajay Parmar et al(2012) ${ }^{2}$ stated that the most common position of mental foramen in relation to the lower teeth in their study was Type 4i,e in line with second premolar. This fact correlates with the similar findings in the present study. The most common type was type $4-62 \%$ and $66 \%$ on right and left sides respectively.

With reference to Table 2,the commonest position has been described in $52.94 \%$ cases in srilanka9.44.08\%(R) and 46.23\%(L) cases in Western India 8,55.7\% (R) and $61.4 \%(\mathrm{~L})$ cases in Turkish mandibles, $45 \%$ in Tanzanian studies10,
$64.3 \%$ in Koreans and $69.2 \%$ in Malay populations $^{13}$

Yesilyurt et $\operatorname{al}(2008)^{5}$ in their study have quoted that the most common position for the mental foramen were i) below the second premolar tooth (Type4) in Chinese, Kenyan Africans and Mongoloid populations ii)posterior to the second premolar (Type 5) in Caucasians and Zimbabweans iii) between the premolars (Type 3) in Negro, British, Central Anatolian and North American white populations

Haganifar and Rokouei(2009) ${ }^{17}$ in their radiological study of the mental foramen, reported that the most common position of the mental foramen was between the 2 premolars -Type 3 being $47.2 \%$

Another study from Turkey has shown that the most common position of the mental foramen was between the $2^{\text {nd }}$ premolars-Type $3(71.5 \% \text { cases })^{14}$

As regards to the situation of the mental foramen with respect to mandibular parameters (Table 3) differences are seen amongst Western India ${ }^{8}$, Turkish ${ }^{5}$, Korean ${ }^{12}$,Srilankan ${ }^{11}$,Thai ${ }^{15}$ and North Indian samples ${ }^{16}$ 
The review of available literature shows that the mental foramen shows racial and ethnic variation. Moreover the variation in the values indicate towards the variational mandibular dynamics of population under consideration

Many of the differences can be attributed to variability in chewing habits of different population leading to differential development of Mandible ${ }^{2}$

The restoration of form and function without violating important anatomic structures are the fundamental goal in surgical management of any patient, one of these is mental foramen, its identification and preservation in periapical surgery, implant surgery, maxillofacial surgery and orthographic procedure is of utmost importance. ${ }^{18}$

\section{CONCLUSION}

The knowledge gained from this study offers valuable insight on the morphology of mental foramen in South Indian population which hither to was not recorded by other authors.

Knowledge of distances from surgically encountered anatomic landmarks may be of assistance in locating these important maxillofacial neurologic structures during many procedures

Therefore a detailed knowledge of mental foramen anatomy and its variations in different population is essential for dentists, orthopedicians and anatomists alike.

\section{Acknowledgement: None}

Conflict of Interest: None

\section{Source of Funding: None}

\section{Ethical Approval: Approved}

\section{REFERENCES}

1. Standring S. Gray's Anatomy. $39^{\text {th }}$ ed. London: Churchill Livingstone;2005

2. Ajay Parmar, Kanan Shah, Bhaskar Patel, Jagdeep Jadav, Bharat Trivedi, Gaurnag
Kothari. Morphological and Morphometric analysis of mental foramen in dry human mandibles. Int $\mathbf{J}$ Med Sci Public Health. 2013; 2(3):654-658

3. Phillips JL, Weller R N,Kulild JC. The Mental foramen:1.Size,orientation and positional relationship to the mandibular second premolar. J Endod 1990 May;16(5): 221-3

4. Rowe AHR .In: Clinical Dentistry. $3^{\text {rd }}$ edi. Oxford: Blackwell Scientific Publications 1986.p.372-83

5. Yesilyurt H,Aydinilioglu A, Kavakli A, Ekinci N, Eroglu C, Hacialiogullari M, et al. Local differences in the position of the mental foramen. Folia Morphol 2008;67(1): 32-35

6. Santini A, Land MA.A comparison of the position of the mental foramen in Chinese and British mandibles. ActaAnat (Basel). 1990;137(3):208-12

7. Wang TM, Shih C, Liu JC, Kuo KJ.A clinical and anatomical study of the location of the mental foramen in adult Chinese mandibles. ActaAnat(Basel) 1986;126(1): 29-33

8. Siddiqui A U,Daimi SR, Mishra PP, Doshi SS, Date JY, Khurana Morphological and Morphometric analysis of mental foramen utilizing various assessment parameters in dry human mandibles. Int J Stud Res 2011; 1(1):19-22

9. Ilayperma I,Nanayakkara G,Palahepitiya N.Morphometric analysis of mental foramen in adult Srilankan mandibles. Int J Morphol 2009;27(4):1019-24

10. Fabian FM. Position, shape and direction of opening of mental foramen in dry mandibles of Tanzanian adult black males. Ital $\mathbf{J}$ AnatEmbryol 2007;112(3):169-77.

11. Prabodha LBL, Nanayakkara BG. The position, dimensions and morphological variations of mental foramen in mandibles. Galle Med J2006;11(1):13-5

12. Kim IS, Kim SG, Kim YK,Kim JD. Position of the mental foramen in a Korean population: A clinical and radiographic study. Implant Dentistry 2006:15(4);404-11

13. Ngeow WC, Yuzawati. The location of the mental foramen in a selected Malay population J Oral Sci 2003;45(3):171-5

14. Gingor K,Ozturk M, Semiz M, Brooks SL.A radiographic study of location of mental foramen in a selected Turkish population on 
Mangala S et.al. Morphological and morphometric analysis of mental foramen in dry, human mandibles of South India.

panoramic radiograph. CollAntropol. 2006; 30(4):801-5

15. Apinhasmit W,Methathrathip D, Chompoopong S, Sangvichien S. Mental foramen in Thais: an Anatomical variation related to gender and side.SurgRadioAnat2006;28(5):529-33

16. Singh S K,Gopinath K, Dhall U, Chhabhra $\mathrm{S}$. Variation in the position and number of mental foramen in mandibles of North Indian population JAnatSoc India1992; 41(1):47-51

17. Haghanifar S, Rokouei M. Radiographic evaluation of the mental foramen in a selected Iranian population. Indian J Dent Res 2009;20(2):150-2

18. Al-Khateeb T, Hamasha AAH, Ababneh KT. Position of mental foramen in a northern regional Jordanian population SurgRadiolAnat2007;29(3):231-7

How to cite this article: Mangala S, Shruthi B N. Morphological and morphometric analysis of mental foramen in dry, human mandibles of South India. International Journal of Research and Review. 2021; 8(7): 212-217. DOI: https://doi.org/10.52403/ijrr.20210729 